Development I3udget for the fiscal years 1952 and 1953 has been published as No. 2 of the series "Federal Funds for Science" (pp. 44. Washington, D.C. : Nat. Sci. Found., I953). 'This study, which is based primarily on data supplied to the Foundation by the twenty-four agencies administering such activities, estimates Federal expenditure on scientific research and development in the year cnded June 30 , 1953 , as 2,200 million dollars, an increase of 400 million dollars on the previous year. Commitments were estimated at 2,400 million dollars as against 2,200 million dollars in 1952, but the rate of increase is slackening, and it is expected that both cornmitments and expenditure will decrease during the fiscal year ending June 30,1954 . It is estimated that about 25 per cent of the expenditure is on work carried out in government-owned installations, 15 per cent on work sponsored at non-profit institutions, and 60 per cent on work sponsored at business organizations. In 1952, twenty-four agencies, and in 1953, twentytwo agencies, administered programmes of research and development, but, of these, seven agencies administered almost 99 per cent of the funds, the Department of Defense accounting for more than 76 per cent and the Atomic Energy Commission for more than 10 per cent of the commitments. Only some 6 per cent of the commitments are for basic research : 121 million dollars in 1952 and 126 million dollars in 1953,29 per cent of this amount, moreover, being administered by the Atomic Energy Commission. Funds for the physical sciences accounted for 90 per cent out of the total, 7-8 per cent going for work in the biological sciences and the remainder for worl in the social sciences. Since 1940, Federal expenditure on research and development has increased more than 22 times, from 97 million dollars to 2,200 millions, the proportion of the Federal budget expended on research and development having also increased, from $1 \cdot 1$ per cent in 1940 to about 3 per cent in 1953.

\section{Medical Research in the United States}

THE growth of medical research in the United States during 1941-53 and of the role of Public Health Service Research Grants are indicated in a review by K. M. Endicott and E. M. Allen (Science, 118,337 ; 1953). They point out that during the decade 1940-50 expenditure on medical research increased about tenfold, and the Federal Government emerged as a major source of financial support, contributing very little to the total of $18,000,000$ dollars in 1941 , but $28,000,000$ dollars out of $115,000,000$ dollars in 1946 and $76,000,000$ dollars out of $181,000,000$ dollars in 1951. Industry provided $55,000,000$ dollars in 1946 and $60,000,000$ dollars in 1951. The pool of trained man-power also increased considerably, as did the output of scientific publications. The tendency to concentrate medical research in some dozen large centres was reversed and several powerful new foci of research appeared. 'The Research Grants Programme of the Public Health Service really began in 1946 with the transfer of fifty projects from the Office of Scientific Research and Development when that agency was dissolved, although the Service had awarded a few grants for cancer research each year since 1937. The new programme had as its objective the improvement of the nation's bealth through the acquisition of new knowledge in all the sciences relatod to health, and, in so far as the new knowledge is sought for the purpose of improving health, the programme is one of applied research. However, many of those receiving grants regard their projects as basic, and policies and procedure under the programmo have been designed to ensure the maximum freedom to those scientific workers who receive grants. Full freedom of publication is given, and once a grant is made there is no direction or interference on the part of the government. Although in 1951 the Public Health Service research grant programme accounted for only 8.8 per cent of the expenditure on medical research, Endicott and Allen consider that the programme has been of the greatest assistance to institutions able and willing to employ and provide basic facilities for competent scientific workers. Some 35 per cent of the funds, or nearly $35,000,000$ dollars, between 1946 and 1953 went on professional assistants to those receiving grants, and many of these assistants themselves now receive grants. Another major effect of the programme has been to stimulate research in neglected fields, particularly research on some of the chronic diseases.

\section{Conflicts of Lcyalty}

THE "Present Question" Conference at Oxford in 1952 on "Conflicts of Loyalties" was concerned with a wider range of problems than its title suggests. The addresses and discussions of most immediate interest to the man of science-those concerned with problems bearing on the conflict of loyalties which may arise out of his professional pursuit of truth and the demands of national security or between religion and science-were reported in the winter 1952 issue of Question, which included the papers of $\mathrm{H}$. Westmann on conflicts of loyalties, of Prof. M. Polanyi on science and faith, of Herbert Reid on sign and symbol, and of Dr. J. H. Oldham on man and truth. The remaining papers and discussions, which are given in the spring 1953 issue of Question (5, Nos. 2-3; pp. 152. London: Hammond, Hammond and Co., Ltd., $1953 ; 7 s$. net), are of much slighter scientific interest, although Angus Maude in his address on morals and politics faces the same issues that Prof. A. V. Hill raised in his presidential address to the British Association shortly afterwards. Generally speaking, these addresses range from the conflicts between the artist's loyalty to the creative impulse and society, between patriotism and world community, between country and party, between functions and personality and between the individual and the family; generally speaking, they stress the importance of human relations and point to the resolution of the problem of relations between the individual and the family or the group, or the larger units of which industry, society and the international community are built up, as holding the key to the elimination of conflicts of loyalty.

\section{Comparative Studies of Apices}

IN a recent paper (C. W. Wardlaw : "Comparative Observations on the Shoot Apices of Vascular Plants", New Phytol., 52, 3, 195; 1953) it is held that while such new types of histological organization as may be observed in the shoot apices of vascular plants will carry their own interests, the extensive anatomical and histological data which are now available should be studied from the genetical, physiological, physical and mathematical points of view, with the view of discovering the causes underlying the homologies of organization which they show. From a comparative examination of apices, all reproduced at the same magnification, it is inferred that the size and metabolism of the meristem cells of the apex are gene-determincd, 